\title{
IMPERIALISM IN NEW TESTAMENT FILMS
}

Jeremy Punt

Old \& New Testament

Stellenbosch University

\begin{abstract}
Imperialism in New Testament (related) films relates to an important aspect of the reception of the Bible in film. After a brief investigation of the concept imperialism, this contribution explores particular instances where imperialism and NT themes intersect in film: the relationship between imperialism, Jesus-followers and Romans; satirical approaches to imperialism in NT films; and, the intersection between imperialism, messianism and violence.
\end{abstract}

Key Words: Imperialism; New Testament; Roman Empire; Violence; Film (Movie)

\section{Film, Bible and Imperialism}

The purpose of this article is to consider imperialism in New Testament (NT) films, and is part of a larger acknowledgement that film has always had a strong if uneven relationship with religion. ${ }^{1}$ The nexus between Bible and film can be approached from the perspective of films that were written, in one way or another, with the Bible in mind. However, 'oldfashioned reverential films' in the style of an early exponent such as The Greatest Story Ever Told (dir. George Stevens, 1965, US) have become uncommon today. Maybe it is not only because of the preferences and prejudices of contemporary audiences, but also because, as one reporter put it: "[m]ajor studios suddenly get distracted when anyone suggests tackling serious religious subjects". ${ }^{2}$ Nevertheless, serious films about religion are still produced, such as The Last Temptation of Christ (dir. Martin Scorsese, 1988, US), ${ }^{3}$ Jesus Christ Superstar (dir. Norman Jewison, 1973, US), or Jésus de Montréal (dir. Denys Arcand, 1989, Canada, 'Jesus of Montreal'). ${ }^{4}$ In such films Jesus is typically pictured in

\footnotetext{
It is claimed that an Episcopal priest, Hannibal Goodwin invented photographic film, and the first photographic film to be shown was on 31 January 1898, The Passion Play of Oberammergau. MR Miles, Seeing and Believing. Religion and Values in the Movies. Boston: Beacon, 1996:6.

$2 \quad$ M Cieply, Can God make it in Hollywood? New York Times, February 22, 2014. http://www.nytimes.com/2014/02/23/sunday-review/can-god-make-it-in-hollywood.html?_r=0 (consulted 27 February 2014).

3 In its final sequence the crucified Jesus is tempted by "a beautiful, androgynous child (Satan in disguise), experiencing a dream, or alternative reality, where he comes down from the cross, marries Mary Magdalene, consummates his marriage and lives out his life as a full mortal man. He learns, on his deathbed, that he was deceived by Satan and begs God to let him 'Be God's son!'”, R Morris, 'The greatest story Hollywood ever told'. The story of Christ and the Bible important to film-making pioneers, The Express, March 30, 2013. http://www.lockhaven.com/page/content.detail/id/544486/-The-greatest-story-Hollywood-ever-told-.html (consulted 3 February 2014). But D Jasper, "On Systematizing the Unsystematic: A Response", in Explorations in Theology and Film. Movies and Meaning, (eds.) C Marsh and G Ortiz; Oxford: Blackwell, 1997:235-244(243) contends that this film "transgresses the demands of its audience, asking too much of them in a medium whose power is effective in as much as, demanding nothing from the viewer, it seems to offer the viewer the power to understand without the need seriously to think or change" (see Cieply, Can God make it in Hollywood?).
}

4 And at the time of writing, films such as Noah (Paramount, 2014) with Russell Crowe; Pompeii (TriStar, 2014) billed as a disaster-adventure film were released; and, Son of God (20 ${ }^{\text {th }}$ Century Fox, 2014) based on 
iconoclastic ways as, respectively in these examples, a so-called normal or real man battling sexual fantasies; as a media figure; or as critic of capitalist consumerism. ${ }^{5}$

The particular choices used here, both in terms of approach to the theme as well as regarding the materials or films studies, will be explained below. In the interest of inclusivity, as far as the genre of film is concerned, popular films or movies as well as films dedicated primarily to a particular (religious) audience are included in my discussion. ${ }^{6}$ In fact, the hermeneutical angle to films which is pursued here is more akin to a cultural studies approach which considers "a film as one voice in a complex social conversation, occurring in a particular historical moment". 7 Films epitomise popular culture and have wide appeal, also engaging people with regard to the more existential issues such as life and death. ${ }^{8}$ And questions about life and death which from time to time include questions about God or the supernatural often permeate even films not expressly pursuing a connection with religion or the Bible, at times touching on associated major concerns such as imperialism. ${ }^{9}$ In fact, some see film's influence extending to the political sphere as well. "Indeed, film may be the most powerful form of artistic expression used in contemporary culture ... films can have an enormous impact on long-term cultural or political issues". ${ }^{10}$ In short, imperialism is more than another motif in films, and where film's lasting impact is considered, imperialism is more than a passing concern.

To investigate the theme of imperialism in NT movies from the reciprocal view that films contribute to the interpretation of the Bible as much as the Bible is an important intertext in many films, opens up further possibilities. This position implies, among other things, a break with that part of conventional biblical scholarship that holds onto objective neutrality in interpretative processes and an impoverished semantic position that a text has only one meaning. Interpretation is of course never neutral and never exegesis in the absolute sense of the word, as if the opposite is both eisegesis and abhorrent. Different levels and forms of eisegesis are all that exist, situated in ideology. Films rewrite scripture in as far as films can lead to a different understanding of biblical texts; moreover, films selectively filter out texts, or characters or themes from the texts, to be used in the films'

Downey and Burnett's mini-series, The Bible, are awaited.

$5 \quad$ See Miles, Seeing and Believing, 19-20. Morris argues, "There is no doubt that the story of Jesus has and always will be one told with more passion than any other story in movies. The sheer dynamics of it, told across many generations and in so many forms, both revered and reviled in equal measure, will certainly endure forever" (Morris, 'The Greatest Story').

$6 \quad$ I will use film and movie interchangeably, whereas some authors reserve 'film' for those forms of the medium which deliberately seeks appreciation at a higher level for its artistic nature, whereas 'movies' would be those items where entertainment value and commercial success are privileged. Browne for example deliberately misquotes playwright Noël Coward, "Even at its most 'commercial' one must not dismiss...' the potency of cheap movies"', D Browne, 'Film, Movies, Meanings', in Explorations in Theology and Film. Movies and Meaning, (eds.) C Marsh and G Ortiz; Oxford: Blackwell, 1997:9-19(10).

7 Miles, "Seeing and Believing", xiii.

8 Generalising, Morris, 'The Greatest Story', thinks that NT films play “to the basic humanity in us all perhaps in the simple hope that it will make us a little more understanding, tolerant and more emotionally enlightened as we move through this thing called life".

9 AJ Bergesen and AM Greeley, God in the Movies. New Brunswick: Transaction Publishers, 2000:17-19; cf. Miles, Seeing and Believing, xiv on film's supposed 'invidious triviality'. Bergesen and Greeley go to great lengths to stress that they are sociologists and not theologians, nor apologists for faith and/or religion, although they profess their denominational faiths. Bergesen and Greeley, God in the Movies, 177. 
stories. ${ }^{11}$ The possibility of reversing the hermeneutical flow between Bible and film has been explored in the past. ${ }^{12}$ The presupposition that biblical narratives or themes can elucidate films has to be matched by the influence of films on the understanding of biblical texts - and, both of these, the flow from the Bible to films and from films to the Bible, are, of course, often present at the same time. One interesting reversal of hermeneutical flow pertaining to imperialism is presented by Life of Brian (dir. Terry Jones, 1979, UK). American films that hardly ever condone imperialism stand in contrast to America which as a country exercises political influence though military invention. British films, again, poke fun at administrators and rulers, but without condemning the regime or its regulatory systems. "The gifts of the Romans to the Jews point to the gifts of the British empire to large areas of the planet". 13

Imperialism's subliminal presence in films needs further elaboration. Such elaboration starts with the silent assumptions and the unrecognised influence of the interpreter on sense-making or hermeneutical events that can develop into a hegemony of sorts. ${ }^{14}$ Especially when it comes to comparisons, such as between the Bible and films, it is not only the intertextual embeddedness of all parties concerned that is important, but also the acknowledgement that comparisons are triadic rather than dyadic. As JZ Smith explains, comparisons are not only between the two elements compared, but always include an implicit 'more than' or 'with respect to' component, connected most often to the audience or interpreters' interests. ${ }^{15}$ While a film does not permit an infinite number of interpretations, a spectator makes sense of it according to his or her education and lifeexperiences as well as a repertoire of film conventions and viewing habits. ${ }^{16}$ Before attending to three broad approaches to the theme of imperialism in NT films, further elaboration of imperialism as well as its relation to NT films is in order.

\section{Imperialism, Writ Large ... and Small}

When and how does a film incorporate imperialism, or become imperialistic? By now it has become clear that the understanding of imperialism needs some fleshing out. In NT films, is imperialism to be broadly conceived on socio-political level, or also religiously? Is imperialism the description of a situation where everyone conforms to the reigning religious or social conventions? Does imperialism imply the attempt to establish an all-encompassing political system or also social structures or conventions? Is imperialism in the end a

11 See G Aichele and R Walsh, 'Introduction. Scripture as Precursor', in Screening Scripture. Intertextual Connections between Scripture and Film, (eds.) G Aichele, and R Walsh; Harrisburg: Trinity Press International, 2002:vii-xvi(vii-viii).

12 R Jewett, Saint Paul returns to the movies. Triumph over shame. Grand Rapids: Eerdmans, 1999; LJ Kreitzer, Pauline Images in Fiction and Film. On Reversing the Hermeneutical Flow. The Biblical Seminar, no. 61; Sheffield: Sheffield Academic Press, 1993.

13 PR Davies, Life of Brian Research, in Biblical Studies/Cultural Studies. The Third Sheffield Colloquium, (eds.) JC Exum and SD Moore; Gender, Culture, Theory, vol. 7; Sheffield: Sheffield Academic Press, 1998:400-414(411).

14 Aichele and Walsh go as far as claiming that "it is that often reticent, third member of the conversation who actually voices and indeed dominates the conversation". However, at the same time the interpreter is also an intertext, which like intertexts in textual, material or other forms "includes and interprets myriad other texts". Aichele and Walsh, 'Introduction', xi.

15 JZ Smith, Drudgery Divine: On the Comparison of Early Christianities and the Religions of Late Antiquity. Chicago: University of Chicago Press, 1990:51. 
question of allegiance, namely about who agrees or disagrees with the perspective of the insiders or powerful few? As often asked in postcolonial discourse, are claims about imperialism dependent on whether a specific group is the object of the exertion of power or equally capable of exercising power over themselves as they see fit? Such questions and their answers both depend on and determines (at least in part) one's notion of imperialism, together with constellations of power and hegemonic frameworks, not to mention the framing of imperialism in film. Browne explains that the narrative plot or narrativity is the engine which drives the audience during the journey on which the film takes them. Underneath the narrative of the film made up of elements such as plot, causality, time and space, range and flow of information, narrative conventions, characters and their development, and so on, is found the ideology of the film. ${ }^{17}$ At times, as in Life of Brian or The Matrix, empire and imperialism are part of the film's narrative, part of the plot and setting and impact the characters. In other films, imperialism is subterranean, as the ideological fibre that constructs and drives the narrative. Of course, in certain films imperialism is both ideologically and narratively present.

start General descriptions of imperialism or empire are helpful to begin with, such as imperialism "as massive concentrations of power which permeate all aspects of life and which cannot be controlled by any one actor alone"; ${ }^{18}$ or even the harsher notion, '[a]t the heart of imperialism is the denial of right and even humanness to those made subject to another's rule'. ${ }^{19}$ Modern theory provides some useful categories for thinking about empire. At the same time, caution is advised: "Its [imperialism's] connotations come from the modern rhetoric of the European nation-state building in the nineteenth and early twentieth centuries, which evoke the polarized categories of 'colonizers' and 'colonized'. Theses connotations presume 'imperialism' to be a single, uniform phenomenon across world history, literature, and geography. But empires are of different kinds, even if not European". ${ }^{20}$ Admitting to the diversity and complexity of describing imperialism, a number of helpful parameters aids our understanding of the notion. The concept of empire is unencumbered by borders as it postulates a regime that effectively encompasses all reality (the civilized world), in the total sense of the word. Empire's rule extends beyond the material and therefore exercises its influence not only on human bodies but on human psychology as well. Empire 'creates the very world it inhabits,' which includes the material or external as well as the internal world as ultimate bio-power. And finally, although empire's practice is 'continually bathed in blood', the concept of empire is always committed to peace, which is a peace that transgresses all conventional boundaries to become 'a perpetual and universal peace outside of history'. ${ }^{21}$

Although these and other broad depictions of imperialism are not without contention, they forefront at the same time on the one hand the complex variety of what is referred to as empire and imperialism, and on the other hand, the appropriateness of including also the notion of hegemony beyond narrow binaries, particular in the sense pointed out by

\footnotetext{
Browne, 'Film, Movies, Meanings', 16-17.

18 J Rieger, 'Christian Theologies and Empires', in Empire and the Christian Tradition: New Readings of Classical, (eds.) DH Compier, Pui-lan Kwok and J Rieger; Minneapolis: Fortress, 2007:1-13(4).

19 T Wiley, 'Paul and Early Christianity', in Empire and the Christian Tradition: New Readings of Classical Theologians, (eds.) DH Compier, Pui-lan Kwok and J Rieger; Minneapolis: Fortress, 2007:47-61(55).

20 JA Harrill, Paul and Empire: Studying Roman Identity after the Cultural Turn. Early Christianity 2, 2011:281-311(288).

21 M Hardt and A Negri, Empire. Cambridge and London: Harvard University Press, 2000:xv.
} 
Gramsci: hegemony as domination by consent. ${ }^{22}$ Imperialism understood as negotiated hegemony means that a vast array of movies is included given the cultural impact and influence of the Christian Bible and the New Testament on Western culture. Imperialism in one sense concerns the presence of Rome and Romans in films of the New Testament period. $^{23}$ But all films are cultural artefacts, and since all culture is ideological, films therefore are inevitably entangled in ideology. This is true of all kinds of films and of films produced in all parts of the world: "in relation to audience, the central dynamic is the relationship of film to culture; or more specifically between cinema and audience/reader and text [viz. the film]". ${ }^{24}$ The dynamic between film and viewer and the central characteristics of the relationship between them must be acknowledged and understood. The role of ideology becomes pronounced especially in our investigation where the focus is on imperialism.

In period films such as Caligula (dir. Tinto Brass, 1979, IT/US), or the older, iconic films such as Ben-Hur (dir. William Wyler, 1959, US), and Spartacus (dir. Stanley Kubrick, 1960, US; more recently, the TV movie by Robert Dornhelm, 2004, US), Rome and the Romans are portrayed along the more stereotypical lines. The binary of oppressor and oppressed is celebrated and often illustrated in appropriately aligned and elaborate casting, costumes and other external phenomena filling out the binary further with regard to aesthetics, morality and the like. Another good example, if no NT film per se, includes the popular box-office hit, Gladiator (dir. Ridley Scott, 2000, US) which tells a story of a Roman general who fell from grace, only to become a gladiator during the reign of the bumbling Emperor Commodus (180-192 CE). In these films, Rome is an overpowering force whose influence permeates both across a broad spectrum but also to the deepest level of people's lives, to the furthest flung corners of Empire. In the form of its figures of power such as governors and soldiers but also in structural format such as slavery and economic structures Rome causes suffering and death with scant regard for the lives of others, especially of non-Romans. But imperialism cuts deeper, and becomes more complex when the ostensible binaries are collapsed into hegemony by assent. A post-binary focused imperialism does not deny the unevenness of power and resulting relationship but shifts the focus to complex power relationships, hybrid identities and the intricate yet sustained intertwined interaction between all those who constitute empire in a specific spatial and temporal context.

A long list of popular films portrays churches or 'the Church' as imperialistic, even if in different ways. For example, in The Da Vinci Code (dir. Ron Howard, 2006, US), the Church attempts to cover up the human nature of Jesus, his sexual relationship with Mary Magdalene, and the existence of their progeny. In Agora (dir. Alejandro Amenábar, 2009,

22 Hegemony in postcolonial thought is domination by consent (Gramsci), "the active participation of a dominated group in its own subjugation", and regardless of the fact that the subjugated numerically outweighs those exercising power over them even if the oppressor or army of occupation may have the advantage in terms of instruments of subjugation such as sophisticated weaponry and the like. "In such cases...the indigene's desire for self-determination will have been replaced by a discursively inculcated notion of the greater good, couched in such terms as social stability... and economic and cultural advancement", SD Moore, Empire and Apocalypse. Postcolonialism and the New Testament. The Bible in the Modern World, vol. 12; Sheffield: Sheffield Phoenix, 2006:101.

23 But themes of hegemony further include and range from gender patterns such as (hegemonic) masculinity to domination or devastation of the earth to rampant capitalism as economic control. And such themes abound across different film genres, from film noir to chick flicks, from blockbuster movies to art-house films. 
Spain) the woman philosopher Hypathia fights for recognition of the wisdom of the Ancients against the early Christian establishment in $4^{\text {th }}$ century Roman Alexandria. The Church, however, is portrayed as unscrupulously and even violently protecting its interests by (literally, also) silencing those voices deemed dangerous to its position. In a film with strong gender undertones the community of the faithful is presented as ignorant and callous. Die Päpstin (dir. Sönke Wortmann, 2009, Germany, 'Pope Joan') is a film about the legend of Johanna who became the $9^{\text {th }}$ century pope Johannes Angelicus until the discovery of her gender. This film portrays a medieval church beset by politicking and strong gender conventions. As for the gender imperialism in these and so many other films, it bears remembering that in the history of the depiction of women in images in the West (influenced by Christianity), it was mostly men that depicted women. Representations were of two opposing kinds, romanticised and glamorised with the Virgin Mary as archetype, or demonised as the daughters of Eve, and thus the cause of sin, sex and death. ${ }^{25}$ Scriptural support for such positions is of course not difficult to find, e.g. Eccl 25:24 claims women as the cause of sin and ultimately then, death; see also e.g. $1 \mathrm{Tm} 2: 14$. With reference to more recent times, Lars von Trier's Breaking the Waves (1996, Denmark) provides a cynical perspective on the church of a small Scottish highlands community. Unlike Jan and Bess who choose options beyond their own comfort and satisfaction, the local and devout church community is portrayed as biased, vindictive and punishing - and powerful. The film betrays, not without irony, an appeal to a divine blessing of events in the face of their condemnation by the local church. ${ }^{26}$

Finally, hegemony is mostly not portrayed as deriving from divine origins. In their avant garde approach to God in the movies, Bergesen and Greeley admit to different portrayals of God in films but claim that the general divine image that emerges is of a persistent and loving, passionate, forgiving God frequently framed as female. This image of God stands in stark contrast to a 'narrow, punitive, rigid and harsh' God, encountered as male patriarch in churches. ${ }^{27}$ And, in the end, Bergesen and Greeley claim that the God of the movies "is the God of the Scriptures - the God of the Hebrew prophets and the God of the Bible - and anyone who doesn't perceive that doesn't know the Bible very well". ${ }^{28}$

25 See Miles, Seeing and Believing, 136.

26 More loosely connected to the NT but with a pronounced imperialist emphasis, the comedy Keeping Mum (dir. Niall Johnson, 2005, UK) tells the somewhat predictable story of a straight-laced priest in a small British parish hampered by strained family relationships and a sterile ministry. His situation takes a turn for the better when he is introduced to humour and the lighter side of life by his homicidal mother in law. In the film Prisoners (dir. Denis Villeneuve, 2013, US) Keller Dover, a struggling carpenter and man of faith, starts with the reciting the Lord's Prayer as the movie begins, and retains a subtle sub-text of faith throughout. Dover's violent reactions towards a suspect, spiral out of control when his daughter and her friend are kidnapped. In a moving account of a father's anguish for his daughter, the extent to which people of faith will go to protect their loved ones is vividly portrayed.

27 Bergesen and Greeley, God in the Movies, espec 173-177. Bergesen and Greeley's reference and framing of the divine as female is, however, portrayed in male grammar: "The Ground of Being is portrayed as loving, patient, determined, and passionate, a God who has fallen in love with His creatures and will stop at nothing to win their love in return; an improvising God who never gives up on His creatures no matter how much they have given up on themselves; a seductive God who calls humans out of themselves and begs them to leave the past behind (even when the past is life itself) and to risk the future". Bergesen and Greeley, God in the Movies, 11. 


\section{Dealing with Imperialism in New Testament Films}

Taking a closer look at the imperialism and NT films nexus within the parameters mentioned above, it plays out in many different ways. The next three sections explore particular instances where imperialism and New Testament themes intersect in film: (1) the relationship between imperialism, Jesus-followers and Romans; (2) satirical approaches to imperialism in NT films; and, (3) the intersection between imperialism, messianism and violence.

\section{- Paul of Tarsus: Imperialism, Jesus-followers and Romans}

A cultural studies approach to film allows one the investigation of aspects not generally associated with the medium. For example, people at times are reluctant to admit to the spirituality of films, as if uncomfortable to discuss religion and films at the same time, and often fail to see how films 'embody our dreams, desires, and aspirations'. ${ }^{29}$ However, with religious films the scales can tip to the other side when conventions of religion exercise a regulative role on a film's plot, as can happen in NT films. Films that engage on a serious level with religious themes, ever since the countercultural films of the 1970s and the rise of blockbuster movies, have generally failed to succeed at the box office. Gibson's The Passion of the Christ (dir. Mel Gibson, 2004, US) 'with its unflinching, often gory account of the crucifixion' and anti-Semitic bent proved to be an exception by earning $\$ 370$ million at the box office. ${ }^{30}$

Faith-based films traditionally focus more narrowly on a niche market, of which the three-hour long TV film, San Paolo (dir. Roger Young, 2000, Italy, 'St. Paul') in which various imperialist encounters intersect, is a good example. ${ }^{31}$ In the first part of the film, the focus falls squarely on Jewish antagonism against the early Jesus followers. The Roman military (led by Gaius, who later tells Reuben 'Rome knows everything') and the Jewish high priests, and to a smaller extent King Herod Antipas, are shown to control and punish, and even kill Jesus-followers. Hegemony is expressed in various ways, but the first part of the film stresses the power exerted by the Sanhedrin against the Jesus-followers, including the flogging of Peter and John on the temple steps. Later Gaius tells Ruben, 'Rome has killed Jesus', and that Ruben is not to let Jesus be reborn through Paul's preaching. Saul and his Sadducee-priest friend Reuben, are very much part of the political and religious elite who determined the lives of others in the community and the Jesus-followers in particular. Much is made of Saul's persecution of the early church; he carries a sword for a good part of the film, wielding it against robbers in defence of travellers (Barnabas and Hagar) but mostly in actions against Jesus-followers.

In the second part of the film, attention shifts to the portrayal of Saul-turned-Paul after his Damascus road experience. As their former persecutor, Paul initially has to win over the

\footnotetext{
29 Ebert in Bergesen and Greeley, God in the Movies, ix.

30 Cieply, Can God make it in Hollywood? The extravagant Passion of the Christ with its reconstructed ancient languages and subtitles, celebrated violence to the extreme, exhibited a distinct anti-Semitic focus and drowned out the film's ostensible focus on love and hope (see Morris, 'The Greatest Story').

31 St Paul (also known as Paul of Tarsus) appears on the list of 15 NT films created by Angel Sanabria, available at http://www.imdb.com/list/rlmLDPmZhxc/ (consulted on 5 February 2014). The DVD version wants to present the film as 'biblical history in word and vision'. Mixed reactions to the film include the comment that "Overall, Biblically this is a horrid representation of the historic, Biblical account of Paul the Apostle" (http://www.christiancinema.com/catalog/article_info.php?articles_id=5930\# consulted 15 February 2014).
} 
other apostles who stand incredulous towards him as Jesus-follower. ${ }^{32}$ Both Herod Antipas (until his death) and also the temple-establishment are shown as political opportunists, posing a risk to the marginalized majority of people. The threats of violence as well as actual physical violence perpetrated by local Roman soldiers - constantly in the background as the focus is on Jewish leaders who act against Jesus followers - increase and culminate toward the end of the film in the murder of Reuben. Paul and others express explicit criticism towards the Empire (Peter warns Paul that neither the Romans nor the priests can save him from the wrath of God; that the Romans will be defeated; and so on). On the one hand, St Paul traces the troubled friendship between Reuben and Paul tragically lost for reasons of faith (although the subtext of possible jealousy over a woman is not quite resolved). But on the other hand, the film also portrays the intricate and difficult yet imperially inscribed relationship between the Roman Empire and Jewish leaders. This is illustrated in the bathhouse scene between Reuben and Roman soldiers in which they physically abuse Reuben; although he is loyal to their cause and in fact betraying his friend, their intimidation underlines both the insecurity typical of imperial agents as well as a subaltern's willingness to suffer pain and humiliation for the sake of apparent goodwill and reward from empire. As Antipas states, "the first rule of politics is not so much to please the people but to please Rome." ${ }^{33}$ The incipient Christian movement is shown to be formatted in the vicissitudes of Roman imperialism and its patronal clients (such as the Sanhedrin), but less obviously perhaps, as a movement increasingly showing signs of an imperialising mission of its own.

Traditional Jesus films can also be mentioned under this heading of the traditionalist portrayal of the Roman Empire with regard to Jesus and his followers. As mentioned above period films such as Caligula, Ben-Hur, Spartacus and more recently, Gladiator tend to promote stereotypical portrayal of imperialism, at least as far as the Roman Empire is concerned. The stark depiction of oppressor-Empire and oppressed-Jews/believers are equally pronounced in a traditional Jesus film such as King of Kings (dir. Nicholas Ray, 1961, US). The story is told against the background of the Empire's general Pompey who ransacked Jerusalem in the hunt for treasure, and the enthronement of Herod as vassal king to Rome in the attempt to quell rebellions in Judea (-)and surroundings. The story of Jesus is interwoven with that of imperial occupation, from teenager Jesus' encounter with the Roman soldiers to Jesus being passed from Pontius Pilate to Herod Antipas and back, and to his eventual crucifixion. The ubiquity of imperialism in material terms, including soldiers and those in power, is framed in terms of the binary of oppressor and oppressed in King of Kings.

\footnotetext{
32 St Paul not only casts an apostolic role for Paul, but also for other early Jesus-movement leaders: Peter probably comes off best, in terms of being accommodating to others; James is portrayed as a stubborn, hardheaded person who only opens up later; and Stephen and John as middle of the road people.

33 Anderson writes about the depiction of the political climate during Jesus' ministry in the (at the time of writing, yet to be released) Son of God (dir. Christopher Spencer, 2014, US) in the New York Times: "In 'Son of God,' the point is emphasized that Caiaphas (Adrian Schiller) and the rest of the Sanhedrin, or Jewish council of Jerusalem, were deathly afraid of the Roman reaction to Jesus' preaching, which was seen as revolutionary. 'We try to show the turmoil of the time,' Mr Burnett [one of the producers] said, 'and how frightened they were in the Sanhedrin about the Romans, who could have shut down the temple and killed thousands of people"', J Anderson, The greatest film role ever cast. Heading off criticism when picking an actor to play Jesus. New York Times, 14 February 2014 http://www.nytimes.com/2014/02/16/movies/headingoff-criticism-when-picking-an-actor-to-play-jesus.html?_r=0 (consulted 17 February 2014)
} 
- Life of Brian: A satirical approach to New Testament Imperialism

Few NT films have had such a lasting impact as Life of Brian. ${ }^{34}$ Given the historical research that went into the making of the film, one scholar goes so far as to claim, "I have long been of the conviction that Monty Python's Life of Brian is an indispensable foundation to any student's career in New Testament studies". ${ }^{35}$ In the past, scholars have interpreted Life of Brian as Christian, confrontational and also as counter-hegemonic. ${ }^{36}$ The film is a satirical look at Brian Cohen's mistaken messianic identity in a film which is creatively scripted in the context which produced the New Testament gospels. Life of Brian tells the story of Brian who grows up resentful of the continuing Roman occupation of Judea notwithstanding his own lineage (his father was a Roman Centurion, Naughtius Maximus). Yearning for Judith whom he met at Jesus' Sermon on the Mount, and hatred for the Romans lead him to join the People's Front of Judea, one of a multitude of quarrelling Jewish separatist movements. Brian manages to escape after his graffiti-protest, and lands up among mystics and prophets, but inadvertently inspires a number of people with some ostensibly religious chatter. The crowd later declares Brian as Messiah, and in an ironic twist of events he ends up on a cross even after Pontius Pilate has set him free. The film portrays Jewish diversity and Roman imperialism of the time in unembellished, if comic terms. While this comedy pokes fun at many social, political and religious issues, probably also at conventions of Jesus-films in general, it also raises some important questions about the first-century world, including Judaism and the Roman Empire. However, as far as imperialism is concerned, "[o]verall, by accepting the common sense of Jesus' divinity and ethical authority, Life of Brian locates itself squarely within the hegemonic network of Christianity". ${ }^{37}$

As hinted above, Life of Brian reverses the hermeneutical flow especially as it pertains to imperialism. ${ }^{38}$ In Life of Brian's insistence on human benevolence, the portrayal of Roman or imperial benevolence ${ }^{39}$ attracts attention in itself but also in contrast to American films with their apathy towards imperial government. ${ }^{40}$ The Roman powers are portrayed,

34 One way in which this film can be construed as imperialist or at least hegemonic, is its relationship to organized Christian religion. While the film's screenplay is billed on Amazon.com as “[t]he classic piece of cinematic blasphemy from 1979", some scholars believe the film functions as criticism on Christian imperialism (C Dyke, "Learning From the Life of Brian. Saviors for Seminars", in Screening Scripture. Intertextual Connections between Scripture and Film, (eds.) G Aichele, and R Walsh; Harrisburg: Trinity Press International, 2002:229-250(240); cf. Davies, 'Life of Brian Research', 406.

35 Davies, 'Life of Brian Research', 400; see 401-406. Davies restates his claim a few times, see e.g., 'Monty Python's use of the New Testament betrays a more knowledgeable and even sophisticated use of the material than a superficial appreciation of its parodic humour realizes". Davies, 'Life of Brian Research', 406.

Dyke, 'Learning From the Life of Brian', 229-250.

37 Dyke, 'Learning From the Life of Brian', 240.

38 Films in the past have succeeded in subverting an imperialism of a different kind: "The development of popular film coincided historically and geographically with the emancipation of public life from church control and patronage" (Miles, Seeing and Believing, 25). However, in religious films the 'democratic' function of popular media in the interpretation of biblical narrative can sometimes be subverted, overturning the emancipatory effect of popular films. The Passion of the Christ is an example of returning to conventional positions, such as a one-sided, biased portrayal of Jews and a spiritualized (unpoliticized) role for Jesus.

But, as Davies, 'Life of Brian Research', 410 points out, those items identified by the film's characters as positive spinoffs of imperial rule, e g aqueducts, roads, peace, irrigation, wine, baths and education is somewhat over-optimistic. Irrigation, wine, and education were in Judea before the Romans arrived.

40 Ironically, "[t]he American Hollywood movie is American imperialism at its most effective". Davies, 'Life of Brian Research', 410 n17; emphasis in the original. 
in true satirical style of course, as rather inept, but also benevolent. For example, during his graffiti-protest, Brian is taught the more correct Latin for the phrase he scribbles rather than being arrested; and, the governor actually orders Brian to be released although through some misplaced support of the crowd, he ends up on a cross. Such portrayals underline both a rather awkward Roman benevolence, as well as that imperialism is not a simplistic matter of an oppressor-oppressed binary. As far as Roman imperialism is concerned, Life of Brian builds on what is known about $1^{\text {st }}$ century Judea. Not only were Jewish feelings towards the Romans rather ambivalent, but various Jewish groupings jostled among themselves for control and power. ${ }^{41}$ The film's portrayal of the clumsiness and thus ambivalence of Roman power provides food for thought in assuming a strict oppressor-oppressed binary - which is not, of course, to deny the inequality of power, its use and the resulting disastrous consequences for the people at large. Brian's final fate, under accompaniment of the satirical 'Look on the bright side of life'-tune, remains a stark reminder that the Empire ultimately exercised the power of the sword. While satire and comedy can numb the presence of hegemony, Life of Brian exacerbates its effects and experience. ${ }^{42}$

\section{- The Matrix: Imperialism, Messianism and Violence}

The science-fiction thriller The Matrix (dir. Andy and Larry Wachowski, 1999, US) exhibits a striking if muted intertextuality using some biblical themes and a strong messianic motif in particular. ${ }^{43}$ The Matrix's abundant biblical, religious and spiritual allusions may not make it a NT film in the traditional sense of the word. ${ }^{44}$ However, this violent sci-fi shoot-'em-up film's existential concern for what constitutes human life and reality, ${ }^{45}$ makes it worthy of discussion under the topic of imperialism in NT films. In an

41 Davies, 'Life of Brian Research', 401-403.

42 Staying with the more tongue-in-cheek approach to imperialism, Bruce Almighty (dir. Tom Shadyac, Universal, 2003) makes for some comparison with Life of Brian. The former is a light-hearted comedy anchored in the today's world and interacting with hegemonic Christianity rather than ancient Rome. Hit by misfortune TV reporter Bruce Nolan complains to God that he is not doing his job correctly. Bruce gets the chance to be God himself for one week, in an entertaining if somewhat predictable film about - for want of a better term - the complexity of being God. Initially Bruce manipulates his own life and people he loves, taking revenge on his rivals; in the end, though, it becomes clear that Bruce really only cares about himself. The imperialism of Bruce Almighty is better understood as hegemony, as enacted in Bruce's aspiration to (but, in the end, withdrawal from) power, in the purported power negotiations between God and Bruce, and the implied broader reach of such power negotiations among all people and God. The two films are worlds apart in more than one sense, yet both Life of Brian and Bruce Almighty reflect an antipathy towards hegemony, whether rooted in deep-seated conventions humorously portrayed, or in mostly cheap laughs.

43 An ever-deepening messianic role is ascribed to Neo in the movie, from the initial flippant yet ironical identification ("Hallelujah, you're my saviour man, my own personal Jesus Christ"), to Neo's own unpreparedness to understand, to Morpheus's statement to Neo, 'You are the One', and his claim that the search is over: The returned or reincarnated messiah has been found. Neo starts what resembles messianic training in preparation of the task ahead, reminiscent of the temptation of Jesus-scenes in the Synoptic Gospels (Mt 4:1-11; Mk 1:12-13; Lk 4:1-13), and is in the process identified as the genuine 'child of Zion' (see J Punt, Empire, Messiah and violence: A contemporary view. Scriptura 80, 2002:259-274; "Messianic victims or victimized Messiah? Biblical allusion and violence in The Matrix", in Sanctified Aggression. Legacies of biblical and post-biblical vocabularies of violence, (eds.) J Bekkenkamp and Y Sherwood; JSOTSS vol.400; Bible in the twenty-first century, vol.3; London: T\&T Clark International, 2003:139-155.

However, more is at hand: e.g. names used for characters in the film are suggestive of biblical or Christian references, including Cypher (cf. Lucifer); Trinity falls in love with Neo; Nebuchadnezzar is the name of the hovercraft that hacks into the Matrix computer, and Zion is the name of the last human city; and, other biblical themes are subtly present: prophecy; belief and faith; the Path; sacrifice; miracle; and revelation.

45 The spiritual undertone of the film is underlined by co-director Larry Wachowski's comment: "[Neo] needs to 
unusual way, various interesting elements of biblical and religious allusions surface and are reworked in The Matrix. ${ }^{46}$ The crucial choice between two worlds, or (the narrow and broad) paths, ${ }^{47}$ is borne out by the prominent use of reflections in the film, and the imperative for the initiates to choose between the red and the blue pill. The one is aesthetically pleasing but leads to dissatisfaction, continued enslavement and eventually unconscious death, the unreal as reality. The other world is dangerous and almost uninhabitable, an apocalyptic desert of wasteland, without promise for the future but it is the real reality. Faith or convictions are central ${ }^{48}$ to rise above the here and now of makebelieve. Initially belief serves the purpose of escaping one's precarious position in the all too real world. But in the longer run, belief facilitates achievement of the fullness of life which presupposes a different world order.

'The One' (signalled already in the lead character's anagram-alias Neo) plays the central role in The Matrix, but his person is involved in violence from the outset. This subtle messianic allusion and the concomitant violence clothed in futuristic metaphor and popular frame of reference emphasize rather than erase the biblical allusions in the film. The movement from one world to another, from enslavement to liberation, is mediated by the messianic or saviour figure. The messiah plays a facilitating role in both calling upon people to break with living the lie as well as showing, and in this way, inaugurating, a different world and a different life - two elements typical of messianism in at least the history of Christianity. ${ }^{49}$ But questions important to imperialism arise from the at times ambiguous portrayal of The Matrix's messianic Neo: Does a messiah require a violent setting to operate, or is the messiah's role related to the subversion of violence? Does the appearance of a messiah initiate or increase existing violence? Are messianic followers prone to and on the receiving end of violence, or do they inflict violence on the messiah, and if indeed, why? In other words, in The Matrix the messianic link with violence reappears and addresses the crucial question concerned with the trends of violent behaviour in the relationship between messiahs and their followers. ${ }^{50}$

basically transcend the Matrix" (Anon, Maximizing the Matrix. Newsweek, 19 April 1999 [Reproduced by permission on the Warner Brothers DVD-edition of The Matrix]). The directors claim that The Matrix "examines the idea of an individual searching for their true self while attempting to escape the box, that we often make of our lives." And, "The Matrix was an idea that I believe philosophy and religion and mathematics all try to answer, which is, a reconciling between a natural world and another world that is perceived by our intellect" (Interview with J Gacta, Z Staenburg and DA Davis, 2000 http://whatisthematrix.warnerbros.com/cmp/chat-johnzachdane_index.html [consulted on 21 January 2002]).

Intertextual echoes from other religious experiences are present too: e.g. Buddhism; Greek mythological allusion; Sophism and the later Gnostic tradition (R Corliss, Popular metaphysics. Time, April 1999. [Reproduced by permission on the Warner Brothers DVD-edition of The Matrix]). Wordplay is intentional; e.g. the use of 'matrix' as mathematical definition but also in reference to the womb. Names were chosen carefully and have multiple meanings (Interview). Other recent films also explore the theme of empire, but do not relate in such significant yet subtle ways to biblical themes as e.g. Star Wars and the Alien trilogy.

In New Testament terms (Mt 7:13-14, Lk 13:24), a choice is to be made, "taking the difficult, 'narrow path' [which] symbolizes hearing and carrying out Jesus' demands, while taking the 'wide path' entails the easier but unfruitful option of only hearing them", Desjardins 1997:38. For the difference between knowing and walking the path, see Mt 7:21-23, Lk 13:25-27.

Taking control of one's own life and becoming 'a believer' (in Neo) implies the need to free people's minds (cf. Rm 12:1-3), at a young age (see Mt 19:13-15, Mk 10:13-16, Lk 17:15-17). "The Matrix is about the birth and evolution of consciousness" (Larry Wachowski, in Corliss, Popular metaphysics), with 'belief in oneself' as prominent emphasis in the movie (Interview).

49 S Freyne, Editorial: The Messiah in history. Concilium, 1993/1:vii-xiv.

50 See also Punt, Empire, Messiah and violence, 259-274; Punt, 'Messianic victims', 139-155. Regarding 
In brief comparison, Son of Man directed by South African film-maker Mark DornfordMay (2006, South Africa) tells a modern-day version of the life of Jesus in a context reminiscent of the townships of contemporary South Africa. It shows how the relationship between imperialism, messianism and violence can be framed differently. In this film, the New Testament story of Jesus is transplanted to a contemporary, decidedly African yet fictive war-torn Republic of Judea. It portrays Jesus as reluctant member of the resistance movement, whose mother Mary appears to be a school teacher. Son of Man does not play down the harsh realities of life in modern Africa. Dirt-strewn, dilapidated township shacks are framed against the natural splendour of the land. The depiction of a dominant regime imposing in various ways on the inhabitants of the land, emphasises the imperialist theme from the outset, and underlies the film's plot. The annunciation to Mary takes place in a school where she could have been a teacher, and she narrowly avoids being massacred with her students, and although Jesus is a resistance leader he does not resort to violence as many others do. ${ }^{51}$ Amidst imperialist excesses and abuses which see on the regime's side children murdered, villages threatened, and Jesus crucified, and on the people's side with both violent resistance against the regime as well as peaceful protest including laying down their babies in the street, the brutality of power and the various reactions to it are highlighted. Empire is accompanied by violence and appears to draw in the messianic figure too. The film invites its viewers to consider whether they are looking at a $1^{\text {st }}$ century gospel plot or whether they are experiencing a modern story of ambition and imperialist endeavour with clashing human aspirations in a power-hungry world. Notwithstanding the film's sometimes awkward treatment of the gospels' narrative structures, Son of Man gives new meaning to the contextual portrayal of biblical narratives. ${ }^{52}$

The nuanced intertextual plays on the biblical themes and narrative in The Matrix and Son of Man highlight the imperialism that permeates the plots of both films, albeit in different ways. The Matrix explores what seems to be the inevitable link between Messiah and violence in an imperialist setting while Son of Man characterises the Jesus narrative as one written on the canvas of empire but with a non-violent Jesus intend on true peace in the world - and suffering violence for his stance. With the relationship between messianism, imperialism, and violence in focus in both films, they come to different conclusions regarding the nature and impact of the relationship.

\section{Conclusion}

Imperialism is an enduring aspect in New Testament-related films, with many popular films also exploring the link between religion and control. Nobody would claim that films are always successful in this regard: "Hollywood's fascination with the Bible has been a rocky

intentional Christian references, the script writer of Man of Steel (Warner Brothers, 2013), says: "I want to be quick to point out that Superman was created by two Jews, and so as much there are parallels to the Christ story there are also parallels to the Moses story. They literally put their son in a bassinet and send him to another world. It's the ultimate immigrant story. I think that it's a saviour story and it's got Old Testament and New Testament aspects" (Goyer and Snyder 2013). Some bloggers insist that Man of Steel carries a strong anti-empire message, see e g http://unsettledchristianity.com/tag/empire-criticism/ (consulted 3 February 2014).

51 The portrayal of Jesus comes across naturally: modern films do not steer away from the difficulty of casting Jesus (Anderson, The greatest film role), unlike older films who did not show Jesus' face, but opted instead for shots of his hands (as in Ben-Hur) or over-the-shoulder views (Morris, 'The Greatest Story').

52 See also the rich collection of essays on various aspects of Son of Man in Walsh, Staley and Reinhartz (2013). 
road and there have been some definite hit-and-miss productions". ${ }^{53}$ However, if popular films can indeed be seen as addressing the question of how people ought to live, ${ }^{54}$ and if imperialism is more than a theme in NT films but a prevailing aspect of Christian life and manifesting in what can be called Christian hegemony, then the focus on control found in mainline films is not surprising. Equally unsurprising is the depiction of oppressoroppressed as stark binary stereotypical of NT films of the Jesus-film variety, while satirical approaches such as Life of Brian tend to both subvert and reinforce imperialism, showing upon the ambivalence of power and how hegemony can often be domination by consent. Messianism plays itself out within a context of imperialism, but a complex range of factors seems to determine the direction and nature of the violence involved. Categories according to which imperialism in NT films can be explored of course can and should be multiplied work, as much as further study if needed for the complex relationships and structures of power in empires in its various guises, in film.

\section{BIBLIOGRAPHY}

Aichele, G and R Walsh 2002. Introduction. Scripture as Precursor. In Screening Scripture. Intertextual Connections Between Scripture and Film, eds. G Aichele, and R Walsh, vii-xvi. Harrisburg: Trinity Press International.

Anderson, J 2014. The greatest film role ever cast. Heading off criticism when picking an actor to play Jesus . New York Times, 14 February 2014 http://www.nytimes.com/2014/02/16/movies/heading-off-criticism-when-pickingan-actor-to-play-jesus.html?_r=0 (consulted 17 February 2014).

Anon, 1999. Maximizing the Matrix. Newsweek, 19 April 1999 (Reproduced by permission on the Warner Brothers DVD-edition of The Matrix).

Bergesen, AJ and AM Greeley 2000. God in the Movies. New Brunswick:

Transaction Publishers.

Browne, D 1997. Film, Movies, Meanings. In Explorations in Theology and Film. Movies and Meaning, eds. C Marsh and G Ortiz, 9-19. Oxford: Blackwell.

Cieply, M 2014. Can God make it in Hollywood? New York Times, February 22. http://www.nytimes.com/2014/02/23/sunday-review/can-god-make-it-inhollywood.html?_r=0 (consulted 27 February 2014).

Corliss, R 1999. Popular metaphysics. Time, April 1999. (Reproduced by permission on the Warner Brothers DVD-edition of The Matrix).

Davies, PR 1998. Life of Brian Research. In Biblical Studies/Cultural Studies. The Third Sheffield Colloquium, eds. JC Exum and SD Moore, 400-14. Gender, Culture, Theory, vol. 7. Sheffield: Sheffield Academic Press.

Desjardins, M 1997. Peace, violence and the New Testament. Sheffield: Sheffield Academic Press.

\footnotetext{
53 Morris, 'The Greatest Story'.

54 Miles, Seeing and Believing, 7-8.
} 
Dyke, C 2002. Learning From the Life of Brian. Saviors for Seminars. In Screening Scripture. Intertextual Connections between Scripture and Film, eds. G. Aichele, and R. Walsh, 229-50. Harrisburg: Trinity Press International.

Flesher, PVM and R Torry 2007. Film \& Religion. An Introduction. Nashville: Abingdon.

Freyne, S 1993. Editorial: The Messiah in history. Concilium (1993/1:vii-xiv).

Goyer, DS and Z Snyder 2013. David S Goyer and Zack Snyder On Man Of Steel's Secrets. http://www.empireonline.com/features/man-of-steel-secrets/p13.

Hardt, M and A Negri 2000. Empire. Cambridge and London: Harvard University Press.

Harrill, JA 2011. Paul and Empire: Studying Roman Identity after the Cultural Turn. Early Christianity 2(3):281-311.

Interview (with J Gacta, Z Staenburg and DA Davis). 2000.

http://whatisthematrix.warnerbros.com/cmp/chat-johnzachdane_index.html (consulted on 21 January 2002).

Jasper, D 1997. On Systematizing the Unsystematic: A Response. In Explorations in Theology and Film. Movies and Meaning, eds C Marsh and G Ortiz, 235-44. Oxford: Blackwell.

Jewett, R 1999. Saint Paul returns to the movies. Triumph over shame. Grand Rapids: Eerdmans.

Johnston, Robert K 2000. Reel Spirituality. Theology and Film in Dialogue. Engaging Culture. Grand Rapids: Baker Academic.

Kreitzer, LJ 1999. Pauline Images in Fiction and Film. On Reversing the Hermeneutical Flow. The Biblical Seminar, no. 61. Sheffield: Sheffield Academic Press.

Miles, MR 1996. Seeing and Believing. Religion and Values in the Movies. Boston: Beacon.

Moore, SD 2006. Empire and Apocalypse. Postcolonialism and the New Testament. The Bible in the Modern World, vol. 12. Sheffield: Sheffield Phoenix.

Morris, R 2013. 'The greatest story Hollywood ever told'. The story of Christ and the Bible important to film-making pioneers. The Express, March 30.

http://www.lockhaven.com/page/content.detail/id/544486/-The-greatest-storyHollywood-ever-told-.html (consulted 3 February 2014).

Punt, J 2002. Empire, Messiah and violence: A contemporary view. Scriptura 80:259-274.

-----. 2003. Messianic victims or victimized Messiah? Biblical allusion and violence in The Matrix. In Sanctified Aggression. Legacies of biblical and post-biblical vocabularies of violence, eds. J Bekkenkamp and Y Sherwood, 139-155. JSOTSS vol. 400; Bible in the twenty-first century, vol.3. London: T\&T Clark International.

Rieger, J. 2007. Christian Theologies and Empires. In Empire and the Christian Tradition: New Readings of Classical Theologians, eds. DH Compier, Pui-lan Kwok and J Rieger, 1-13. Minneapolis: Fortress.

Smith, JZ 1990. Drudgery Divine: On the Comparison of Early Christianities and the Religions of Late Antiquity. Chicago: University of Chicago Press.

Walsh, R 2005. Finding St Paul in Film. New York \& London: T\&T Clark.

Walsh, R, JL Staley and A Reinhartz, eds. 2013. Son of Man. Reflections on a 'South African Jesus' Movie. The Bible in the Modern World, vol. 53. Sheffield: Sheffield Phoenix. 
Wiley, T 2007. Paul and Early Christianity. In Empire and the Christian Tradition: New Readings of Classical Theologians, eds. DH Compier, Pui-lan Kwok and J Rieger, 47-61. Minneapolis: Fortress.

\section{Filmography}

Agora (dir. Alejandro Amenábar, 2009, Spain).

Ben-Hur (dir. William Wyler, 1959, US).

Breaking the Waves (dir. Lars von Trier, 1996, Denmark).

Bruce Almighty (dir. Tom Shadyac, Universal, 2003).

Caligula (dir. Tinto Brass, 1979, IT/US).

Die Päpstin (dir. Sönke Wortmann, 2009, Germany, 'Pope Joan').

Gladiator (dir. Ridley Scott, 2000, US).

Jesus Christ Superstar (dir. Norman Jewison, 1973, US).

Jésus de Montréal (dir. Denys Arcand, 1989, Canada, 'Jesus of Montreal').

Keeping Mum (dir. Niall Johnson, 2005, UK).

King of Kings (dir. Nicholas Ray, 1961, US).

Life of Brian (dir. Terry Jones, 1979, UK).

Prisoners (dir. Denis Villeneuve, 2013, US).

San Paolo (dir. Roger Young, 2000, Italy, 'St. Paul').

Son of God (dir. Christopher Spencer, 2014, US).

Son of Man (dir. Mark Dornford-May, 2006, South Africa).

Spartacus (dir. Stanley Kubrick, 1960, US).

The Da Vinci Code (dir. Ron Howard, 2006, US).

The Greatest Story Ever Told (dir. George Stevens, 1965, US).

The Last Temptation of Christ (dir. Martin Scorsese, 1988, US).

The Matrix (dir. Andy and Larry Wachowski, 1999, US).

The Passion of the Christ (dir. Mel Gibson, 2004, US). 